\title{
日本の中学校理科授業は米国の授業よりも探究的か？ 一中学校理科教員の意識調査の日米比較研究一
}

\begin{abstract}
土佐 幸子 $^{1}$
【要約】

米国においては 1996 年に全米科学教育スタンダードが発行されて以来, 探究を通しての理 科学習は理科教育の大きな柱である。しかし, 2006 年のTIMSS 理科授業ビデオ研究において, 米国の中学校理科授業は事実や定義の伝達を基に展開される場合が多く，日本の授業に比心゙ て探究的ではないことが指摘された。本研究は日本と米国の中学校理科教員が, 探究的指導 法に関してどのような意識をもっているかということを質問紙によって調査した（N=191）。 「理科の探究的指導法に関する意識調査 [STAIB]」という質問紙の内容を開発するにあたり, 複数の計量心理学的要素を考慮した。因子分析を行ったところ，10 個の因子が特定され，こ れらの因子を従属変数とする多変量解析では, 日米の違いに統計的有意差が見られた。また, 個々の因子における日米の違いを調べたところ, 日本の中学校理科教員は米国の教員よりも 探究的指導に賛成する度合いが低く，生徒の活動や質問を積極的に助けることを躊躇する傾 向があることが明らかになった。得られた知見が教員養成を含め, 日米の理科教育に関して 示唆することを議論する。
\end{abstract}

[キーワード] 中学校理科, 国際比較, 探究的指導法, TIMSS 理科授業ビデオ研究

\section{1.はじめに}

\section{1 問題の所在}

近年, 理科において国際学力調査の結果を受け, 子どもの思考力・判断力・表現力を育成する探究的 な活動が重要視されている（文部科学省, 2016)。ま た, 次期中学校学習指導要領理科の目標にも「自然の 事物・現象を科学的に探究するために必要な資質・能 力を次のとおり育成することを目指す」として 3 項 目が記され, 科学的な探究の重要性が高まっている。 (文部科学省, 2017)。しかし, 探究の定義は学習指 導要領に記載されておらず, 実際にどのような活動 を指すのかは明らかでない。米国では, 全米科学教 育スタンダード（National Research Council [NRC, 全米研究評議会], 1996）に探究 [Inquiry］の定義が "Scientific inquiry refers to the diverse ways in which scientists study the natural world and propose explanations based on the evidence derived from their work. (p. 23)”と記述され, “scientific inquiry is at the heart

\footnotetext{
${ }^{1}$ 新潟大学教育学部
}

of science and science learning（p. 15）[科学的探究は 科学の, そして理科学習の中心である。(筆者訳)]” と述べられている。探究的な活動を通して, 科学的 な概念のもつ意味を自ら納得して理解することが理 科学習の本質であると捉えられ, 探究の能動的な過 程は現実社会における科学的な判断力を育むと考え られている (Bybee, 2000)。探究的指導法が子ども の科学的概念理解に効果的であることは, 多くの研 究から示唆されており (Anderson, 2002 ; Von Secker, 2002),「探究」は理科教育者の合言葉のようになっ ている (NSTA, 2004)。また, 2013 年に発表され, 州ごとの導入が進行中の次世代科学スタンダード においても，探究は “Practices”と名を改め，基本と なる 3 領域の 1 つとて重視されている (Achieve, 2015)。

しかし米国では，理科教育界で探究の重要性が明言 されているにもかかわらず，実際の教室で探究的指 導法が実践されることが少ないことが報告されている (Lotter, 2004； Reiff, 2002 ; Simmons ら, 1999)。特 に TIMSS 1999 理科授業ビデオ研究（Roth ら，2006） において，米国で収録された 8 年生（日本の中学 2 


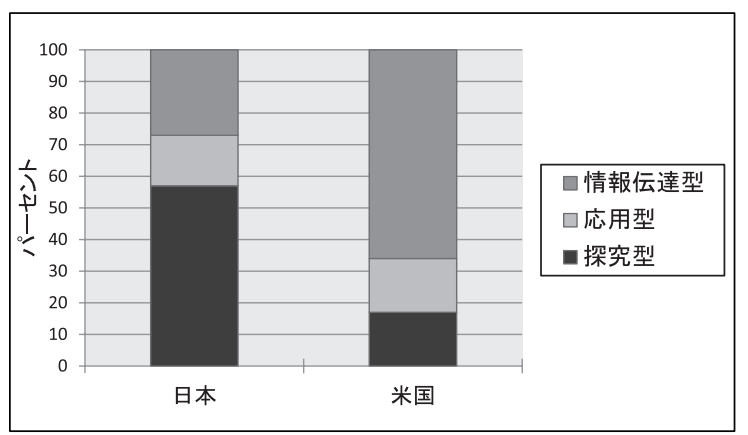

図 1 中学 2 年理科授業における展開方法のパーセン テージの日米比較（Roth ら, 2006 より筆者が作成）

年生に相当）の 88 の理科授業のうち, $66 \%$ の授業で 事実や定義，アルゴリズムの習得を主とする展開が なされていたことが明らかになった。残りの $34 \% の$ 授業は, 概念, 経験, パターン, および説明の間に 関連性をもたせる活動が主となる授業展開であった が，データや経験から帰納的に説明を導き出す「探 究型」の授業は全体の $17 \%$, 命題を検証する「応用 型」の授業が $17 \%$ であた。対照的に, 同研究で収 録された 95 の日本の中学校 2 年の理科授業において, $72 \%$ が関連性をもたせる授業展開をしており, 探究 的な授業は全体の $57 \%$ と分析された（図 1)。果たし て, 日本の中学校理科授業は米国の理科授業に比べ て探究的なのであろうか。小倉（2004）によれば, 日本の TIMSS 1999 理科授業ビデオ 4 つを分析した 27 名の米国理科教員は, 日本の中学校理科教員の指 導法について,「正しい答えは1つしかないという概 念を生徒に教え込んでいた。」「生徒への質問は表面 的なものが多く, 生徒から熟考した思慮深い答えを 得ることは期待していないように見えた。」などのコ メントを共通して挙げたと報告している。日本で探 究的指導が多く実践されているとは言い難いのでは ないかと考えられる。

このように探究的指導法に関して相反する研究結 果を前にして, 中学校理科教育のより詳しい日米比 較を行うことは重要である。探究的指導法を切り口 に日米比較研究を行うにあたり, 教員の探究的指導 法についての理解に関する認知面, 興味や関心とい う情意面, さらに実際に教室で行われている実践面 の 3 つの側面とそれらの相互関係を調べることが, 全体像を捉えることにつながると考えられる。多面 的にとらえることにより，日米の相違点を特定し， 改善点を明らかにすることができると予想される。

\section{2 研究の背景}

理科教育を日米比較する先行研究は過去にも行わ れているが，生徒の学力調査比較であるか（国立教育 政策研究所, 2015a；2015b； Lawson, 1990；Takemura ら，1985），小学校における指導法全般に関する研究 が多い（Linn ら，2000；Takemura ら，1993)。

中学校理科の実践面における日米授業比較として, Tosa $(2009 ; 2011)$ の先行研究がある。この研究で は, 教師の働きかけと生徒の自主性の 2 方向に着目 した授業分析および教師インタビューを通して，日 本の中学校の理科授業と米国の授業を比べている。 具体的な授業展開としては，日本で観察された 14 授 業すべてにおいて，教科書に記載された科学的な課 題が取り上げられ，課題は生徒による実験・観察に よって検討されていた。多くの授業で, 生徒がガス バーナーや顕微鏡など本格的な器具を用いた実験・ 観察を教員の指示に従って行い，生徒自身がその結 果からわかったことをワークシートやノートに記入 していた。しかし, 終末の一斉形態のまとめの時間 において，実験・観察がどんな結果になるべきだっ たのかということについて，教員が「正解」を述べ ることが多く，生徒はそれを書き写す場面が頻繁に 見られた。授業に予想，実験・観察，考察という探 究的活動の一連の要素が多く含まれていたことは, TIMSS 理科授業ビデオ研究で示されたことと一致す る。日本の中学校授業は教科書に沿った教科内容を 重視し, 予想や実験, 結果の考察という探究的活動 の要素を多く含むことが明らかにされた。さらに， インタビューを通して, 日本の中学校理科教員の多 くが, 授業中, 生徒の活動の結果から科学的概念を 導くことを重視していたことが明らかになり，実践 結果とインタビュー結果の一致が見られた。

他方, Tosa $(2009 ； 2011)$ の研究によれば, 日本 の理科授業で，生徒が科学的概念を自分の言葉で理 解できるように教員が支援する場面や，生徒の自主 性が尊重される場面は稀であった。すなわち，授業 分析を通して，日本の授業では教員が生徒に積極的 に働きかけ，自主的な概念構築や既有知識との関連 付けを促すことが少ないということが明らかにされ た。この結果は TIMSS 理科授業ビデオ研究において なされた，授業展開を知識伝達，応用，探究という 3 つの型に分けるという単なる分類から一歩深く踏 み込み，教師の働きかけと生徒の自主性という尺度 に着目して授業展開を調查したときに, 初めて見出 された研究結果である。また，インタビューを通し て, 教員が助けてしまっては生徒の思考力を伸ばす ことにならないと述べた教員もいることがわかった。 
本研究では, 探究的指導法に関する日米の相違点 をさらに明らかにするべく, 教員の情意面について 調査研究を行う。研究課題は「探究的指導法に関す る中学校理科教員の意識は, 日米間でどのような相 違点があるか。」である。

現職の中学校理科教員に関する国際調査として, TIMSS における教師質問紙調査を含むことができ るが, 項目の多くは, 教師の背景, 学校, 指導の教 科内容など，現在の状況に関する情報を収集するも のである (NCES, 2015)。本研究において対象とし た理科の探究的指導法に対する教員の意識に関する 質問は TIMSS 2015 に 1 問あるが，残念ながら，そ の調査結果は報告書に含まれていない（Martinら， 2016)。また，TIMSS 2011 以前の質問紙調查におい て, 探究的指導法に対する教員の意識に関する質問 は見当たらない（NCES, 1995；1999；2003；2007； 2011)。従って,「理科の探究的指導法に対する中学 校教員の意識」に特化し, 多岐に渡る質問項目を用 いて質問紙調査した日米比較研究は先例がないと考 えられる。

また, 中学校教員の指導法に関する意識の国際調査 として, OECD 国際教員指導環境調査（TALIS） 2013 (国立教育政策研究所，2014）があるが，これは理科 に限らず，教科全般に関する調査であり，本研究の 対象とする「理科の探究的指導法に対する教員の意 識」に関する調査ではないことを補足しておく。

\section{3 研究目的}

本研究の目的は, 国際比較を通して, 日本と米国 のそれぞれの国で，理科教育に関してどのような点 が不足していたり，また強調されていたりするかを 明らかにすることである。この大きな目的を達成す るため，本論文では教員の指導法に関する意識につ いて, 日米における相違点を明らかにすることに焦 点を当てて調査を行う。教育は文化的な営みである (Stigler ら，2000)。1つの国の中では, 伝統的な価 值観や慣習が日常的であり, 文化的背景の中で, 当 たり前とみなされている通常の教育活動の意味を捉 え直すことは容易ではない。国外のものと対比させ ることにより，1つの国の中では見えなかった新た な展望が得られることが期待される。しかし, 国際 比較研究には言語の問題はもとより, 比較基準を揃 えた調査方法の開発や国の枠を跨いでの調査実施な ど幾多の困難な点が伴う。本研究では研究者の日米 2 力国に基盤を置く状況を活かし, 日米教員の協力 の下に国際調査が可能となった。

本研究において探究的指導法とは, 全米科学教育久
タンダード（NRC, 1996）とその解説書（NRC, 2000） に記述された子どもの探究的活動を促すような指導 方法を指す。NRCの解説書によれば，子どもの探究 的活動とは次の 5 つの特徵的な場面を含む。すなわ ち，（1）科学的な疑問に取り組む，（2）疑問を解決 するために証拠を見つける，（3）証拠から説明を考 える，(4）説明を社会的に認められた科学的知識と 結びつける，さらに（5）説明を周りの人に伝え，そ の正当性を議論する，という科学の方法に則った一 連の活動である。全米科学教育スタンダードには, それらの活動を支援するため，子どもの学習に助言 を与えたり，焦点化させたり，励ましたりすること が教員の役割であると述べられている（p. 33）。その 際，重要なことは探究を促すために，特定の指導法 が推奨されるわけではなく, 複数の指導法を組み合 わせて子どもの探究的活動を保障することである。

\section{2. 研究の方法}

本研究では, 日米の中学校理科教育を比較するに あたり，質問紙を用いて探究的指導法に関する教員 の意識調查を行った。探究的学習の定義は, 前述 のように全米科学教育スタンダードに従い（NRC, 1996)，質問紙が作成された。得られたデータは，因 子分析，多変量および 1 変量分散分析により，定量 的に分析された。

\section{1 調査対象および時期}

質問紙調查には 191 名（日本 134 名，米国 57 名） の中学校理科教員が回答した。回答者は日米それぞ れの国の理科関係者のメーリングリストで募集し, 呼びかけに応じた現職中学校理科教員である。質問 紙調査はインターネット上で回答できる形で行われ た。調査は 2008 年 5 月から 6 月にかけての 2 週間半 に日米両国で同時に実施された。回答者の性別と年 齢別と教職経験年数別を表 1 に示す。何らかの理由 により，教員の背景を問う項目に回答した日本教員 は少なかった。表 1 に含めたように, TIMSS 2007 の 教師質問紙調査（IEA，2007）による結果と比較する と，本研究の質問紙回答者は日米それぞれの国全体 の統計と比較して，性別は概ね同様であった。年齢 に関しては，日米共に 20 代の回答者の割合が小さ く，40 代あるいは 50 代以上の回答者の割合が大き かった。教職経験年数に関しては, 全体の統計と矛 盾しない。学問的背景 (大学および大学院での専攻) と教員免許に関するデー夕を表 2 と表 3 に示す。表 からわかるように，日本の回答者は理学のみを専攻 し，中高の免許保持者が多かった。 
表 1 日米の回答者の大学・大学院での専攻

\begin{tabular}{|l|c|c|}
\hline \multirow{2}{*}{ 大学・大学院での専攻 } & \multicolumn{2}{|c|}{ 回答者 } \\
\cline { 2 - 3 } & 日本 $(\mathrm{N}=59)$ & 米国 $(\mathrm{N}=49)$ \\
\hline 理学と教育学 & $7 \%(4)$ & $51 \%(25)$ \\
\hline 理学*のみ & $64 \%(38)$ & $14 \%(7)$ \\
\hline $\begin{array}{l}\text { 教育学のみ } \\
\text { (理科教育を含む) }\end{array}$ & $29 \%(17)$ & $29 \%(14)$ \\
\hline 理学でも教育学でもない & $0 \%(0)$ & $6 \%(3)$ \\
\hline
\end{tabular}

括弧内の数字はそれぞれの項目の人数を示す。

*工学, 農学, 家政学を含む。

表 2 質問紙回答者および TIMSS 2007 調査の性別・ 年齢別・教職経験年数別のパーセント

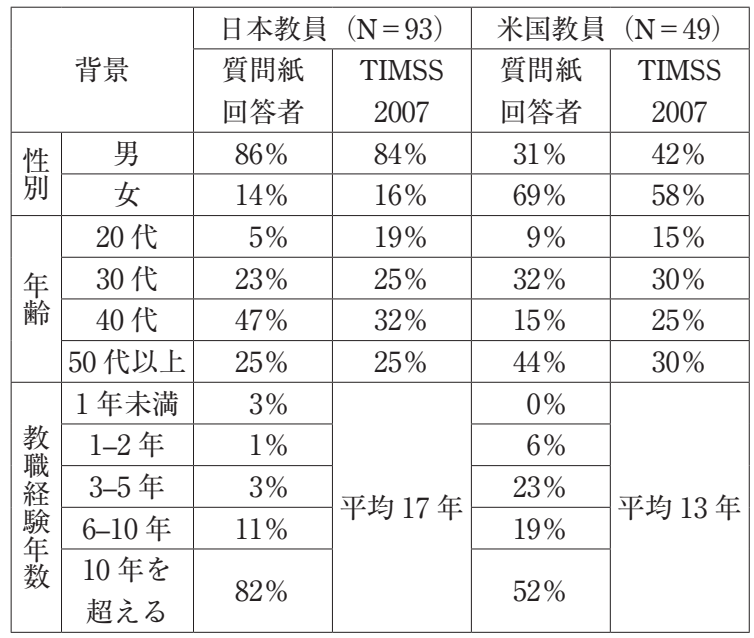

表 3 日米の回答者の保持する教員免許の種類

\begin{tabular}{|l|c|c|}
\hline \multirow{2}{*}{$\begin{array}{c}\text { 回答者の保持する } \\
\text { 教員免許の種類 }\end{array}$} & \multicolumn{2}{|c|}{ 回答者 } \\
\cline { 2 - 3 } 小学校のみ & 日本 $(\mathrm{N}=93)$ & 米国 $(\mathrm{N}=49)$ \\
\hline 中学校のみ & $0 \%(0)$ & $8 \%(4)$ \\
\hline 高校のみ & $0 \%(0)$ & $35 \%(17)$ \\
\hline 小学校・中学校 & $1 \%(1)$ & $12 \%(6)$ \\
\hline 中学校・高校 & $61 \%(57)$ & $31 \%(15)$ \\
\hline 小学校・中学校・高校 & $31 \%(29)$ & $2 \%(1)$ \\
\hline 無免許 & $0 \%(0)$ & $2 \%(1)$ \\
\hline
\end{tabular}

括弧内の数字はそれぞれの項目の人数を示す。

本研究の対象となった参加者は, 日米の理科教育 関係のメーリングリストの登録者の中でも自ら研究 に参加を申し出た現職の中学校理科教員である。サ ンプルの代表性に関して, 20 代の回答者が少なかっ たことが 1 例となるように，本研究の対象が日米の 中学校理科教員全体を代表しているとは言い難い。 しかし, 公的な調査でない限り, 無作為抽出された
学校教員から回答を得ることは難しい。また，教員 の個人名を入手することが難しい上に，無作為に学 校に質問紙を送っても回答を得られない場合が多い。 実際，試験調査において，米国のある州の公立中学 校を無作為に 20 校選び，各校の「理科教諭」宛に質 問紙を郵送したが，3 度依頼文を送ったにも関わら ず，返送されたのは 3 通であった。メーリングリス 卜を通しての参加者募集は, 現職理科教員から回答 を得る実施可能な方法であると言えよう。より広範 囲な理科教員に参加を求めるため，米国は理科教師 学会のメーリングリストを利用させてもらい，日本 では全国的に 1,000 名を超える理科教育関係者が登 録するメーリングリストを利用させてもらった。広 範囲の理科教師に参加を呼びかけることができたと 考える。従って, 本研究は実施可能な範囲内で, 日 米共に中学校理科教員という全体の中の, 探究的指 導法の調査に関心をもつ一部を対象としたと考える。

\section{2 調査項目}

質問紙は現職中学校理科教員の探究的指導法に関 する意識を調査するものである。文献を紐解けば, 探究的指導法に関する先行研究を多数挙げることが できるが，「探究的指導法に関して教員の意識を調査 する質問紙」は，2006 年に Smolleck らが小学校教員 志望学生を対象とする質問紙を開発するまで, 先行 例が見当たらなかった（Smolleck ら，2006）。本研究 では，現職中学校理科教員を対象とした質問紙を開 発した。そのため, 計量心理学的要素を考慮して以 下の 4 つのカテゴリーについて尺度を設け，36の質 問項目の作成を行った。

(1)探究的指導法に対する全般的な好感度

(2)探究的学習に扔ける生徒の活動の重要性

(3)探究的な指導を妨げる要素

(4)探究的な指導に対する自信

教育学研究において, 一般に「態度」というと, 認知的, 情意的, および行動的要素を含む（Gable, 1986 ; Shrigley ら，1988)。それぞれの要素について 潜在変数のカテゴリー（分類）を設けた。態度の認 知的要素には信念という「人が正しいと受け入れて いる情報（Koballa \& Crawley, 1985, p. 223）」が含ま れる。そこで，質問項目には教員の信念として「(3) 探究的な指導を妨げる要素」と「(4)探究的な指導に 対する自信」を含めた。例えば，(3)のカテゴリーの 例には「探究的活動を通しての教え方は, 準備に時 間がかかり過ぎる。という教員の準備時間を探究の 妨げと感じているかどうかを問う項目が挙げられる。 (4)のカテゴリーの例では「授業中，私がすぐに答え 
られないような質問が生徒から出たら，私はそれを 生徒が問題をさらに深く追究する好機だと捉える。」 というように，探究的活動に関する教員の自信を問 う項目が挙げられる。また，情意面に関する要素と して「1探究的指導法に対する全般的な好感度」を 含めた。このカテゴリーの例には「中学校理科教育 において，「意欲的に探究する活動を通して」指導す ることが強調されるのは大事なことだと思う。ととい うように, 探究的指導法に関して教員が好意的かど うかを問題にする項目が含まれる。「態度」の中の行 動的要素のカテゴリーとして「(2)探究的学習におけ る生徒の活動の重要性」を含めた。(2)のカテゴリー には「私の理科の授業において, 1 人ひとりの生徒 が実際の証拠から説明を考え出すのは，私にとって 大事なことである。というように，「証拠から説明 を考え出す」という行動を大事だと思うかどうかと いう項目が含まれる。表 5 に 36 の質問項目の内容の 記述とそれらの属するカテゴリーを示す。

各質問項目について回答者が思う度合いを 5 件法 （まったくそう思わない $=1$ ，そう思わない $=2$, どち

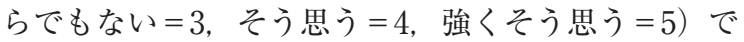
回答を求めた。さらに, 質問紙には年齢, 学歴など デモグラフィックに関する情報を問う 7 項目が加え られた。作成された「理科の探究的指導法に関する 意識調査 (survey for measuring Science Teachers'Attitudes towards Inquiry-Based teaching [STAIB])」は, 理科教育学に精通した 3 人の専門家によって, 内容 の妥当性が検討され, 専門家の助言に従って数回に わたって修正が加えられた。最終的に, 日米に拀け る試験調査で質問紙の妥当性が確認された上で調査 は実施された。紙面の都合上, STAIB の妥当性と信 頼性に関する議論については他の機会に譲る。

\section{3. 結果}

本研究では, 日米の中学校理科教員の探究的指導法 に関する意識の相違点を明らかにするために, STAIB を用いた質問紙調查を行い, そのデータの統計学的 分析を行った。分析には統計解析ソフトウェア SPSS を使用した。日本, 米国, 全体について質問紙調査 の回答の項目別平均と標準偏差を表 4 に示す。

\section{1 質問紙の尺度の信頼性}

デー夕全体（N=191）に対するクローンバック のアルファは 0.80 であり, 質問紙の尺度は中学校 理科教員の探究に関する意識を調査する上で, 内的 整合性があり，信頼性があるとみなせる（DeVellis， 2003）。日本のデー夕（N=134）のみのアルファ值
表 4 質問紙調査 36 項目に対する日米の回答の項目別 平均と標準偏差（カッコ内）

\begin{tabular}{|c|c|c|c|}
\hline 項目 & 日本 & 米国 & 全体 \\
\hline Q1 & $4.32(0.61)$ & $4.60(0.81)$ & $4.41(0.69)$ \\
\hline Q2 & $3.01(0.81)$ & $3.42(1.09)$ & $3.15(0.93)$ \\
\hline Q3 & $3.69(0.96)$ & $4.37(0.73)$ & $3.91(0.94)$ \\
\hline Q4 & $2.28(0.99)$ & $1.90(0.91)$ & $2.16(0.98)$ \\
\hline Q5 & $4.43(0.57)$ & $4.46(0.54)$ & $4.44(0.56)$ \\
\hline Q6 & $3.92(0.86)$ & $4.31(0.62)$ & $4.05(0.81)$ \\
\hline Q7 & $4.38(0.55)$ & $4.54(0.50)$ & $4.43(0.54)$ \\
\hline Q8 & $4.25(0.62)$ & $4.19(0.68)$ & $4.23(0.64)$ \\
\hline Q9 & $4.17(0.69)$ & $4.42(0.61)$ & $4.25(0.67)$ \\
\hline Q10 & $4.09(0.81)$ & $4.42(0.61)$ & $4.19(0.63)$ \\
\hline Q11 & $4.03(0.81)$ & $4.37(0.64)$ & $4.14(0.77)$ \\
\hline Q12 & $4.25(0.71)$ & $4.45(0.50)$ & $4.32(0.66)$ \\
\hline Q13 & $4.12(0.74)$ & $4.33(0.66)$ & $4.19(0.72)$ \\
\hline Q14 & $3.66(0.83)$ & $4.23(0.72)$ & $3.85(0.84)$ \\
\hline Q15 & $3.89(0.75)$ & $3.91(0.75)$ & $3.90(0.74)$ \\
\hline Q16 & $4.33(0.68)$ & $4.18(0.88)$ & $4.28(0.75)$ \\
\hline Q17 & $4.50(0.50)$ & $4.56(0.50)$ & $4.52(0.50)$ \\
\hline Q18 & $3.94(0.75)$ & $3.94(0.85)$ & $3.94(0.78)$ \\
\hline Q19 & $4.38(0.65)$ & $4.65(0.48)$ & $4.47(0.61)$ \\
\hline Q20 & $4.12(0.66)$ & $4.60(0.49)$ & $4.28(0.65)$ \\
\hline Q21 & $4.03(0.70)$ & $4.45(0.58)$ & $4.17(0.69)$ \\
\hline Q22 & $2.92(0.81)$ & $2.78(0.84)$ & $2.88(0.82)$ \\
\hline Q23 & $3.94(0.87)$ & $4.43(0.50)$ & $4.10(0.80)$ \\
\hline Q24 & $4.21(0.67)$ & $4.23(0.63)$ & $4.22(0.66)$ \\
\hline Q25 & $3.96(0.63)$ & $4.38(0.67)$ & $4.10(0.67)$ \\
\hline Q26 & $3.63(0.85)$ & $4.50(0.51)$ & $3.92(0.86)$ \\
\hline Q27 & $4.18(0.63)$ & $4.31(0.65)$ & $4.22(0.64)$ \\
\hline Q28 & $3.62(0.86)$ & $4.51(0.55)$ & $3.91(0.88)$ \\
\hline Q29 & $3.22(1.14)$ & $3.49(1.17)$ & $3.31(1.15)$ \\
\hline Q30 & $2.56(0.95)$ & $2.22(0.94)$ & $2.45(0.96)$ \\
\hline Q31 & $2.82(0.94)$ & $2.69(1.13)$ & $2.77(1.01)$ \\
\hline Q32 & $3.46(1.07)$ & $2.74(0.99)$ & $3.22(1.10)$ \\
\hline Q33 & $3.81(0.93)$ & $2.46(0.94)$ & $3.36(1.13)$ \\
\hline Q34 & $3.21(1.00)$ & $3.04(1.11)$ & $3.15(1.04)$ \\
\hline Q35 & $4.05(0.91)$ & $4.17(0.68)$ & $4.09(0.84)$ \\
\hline Q36 & $3.54(1.03)$ & $3.83(0.82)$ & $3.64(0.98)$ \\
\hline & & & \\
\hline
\end{tabular}

は 0.82 であり,より高い信頼性を示した。米国の データ（N=57）のみのアルファ值は 0.77 と少し低 かったが，それでも信頼性があるとみなせる範囲で ある（DeVellis, 2003）。

\section{2 因子分析}

デー夕全体（N=191）に対して，因子分析を行っ た。因子分析には Kaiser の正規化を伴うバリマック ス回転による主成分分析を用い，行列の回転は 34 回 


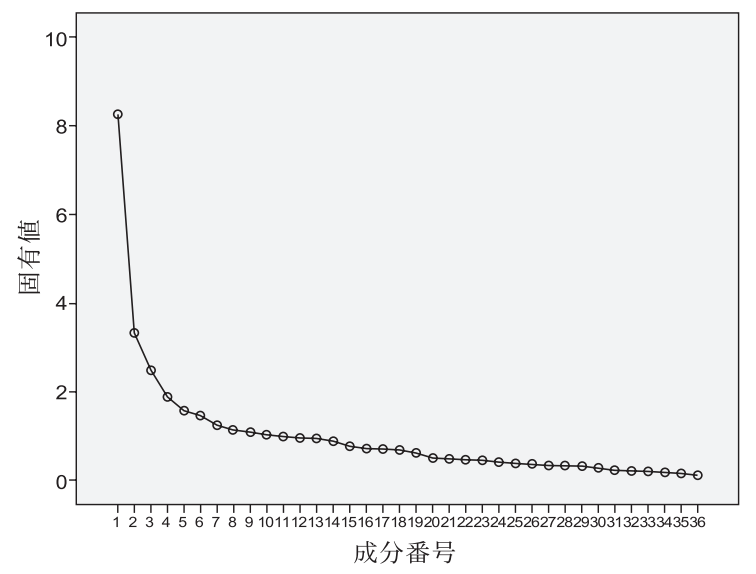

図 2 因子分析におけるスクリープロット

で収束した。1 以上の固有值をもつ 10 個の因子が抽 出された。データの $65 \%$ がこれらの因子で説明でき る。スクリープロットを図 2 に示す。因子 7 以上は プロットの平らな部分に属するように見えるが, 10 個の因子はどれも因子負荷が 0.5 以上の項目を含む ので，妥当な因子とみなした。表 5 に 1 から 10 の各 因子の項目ごとの負荷量を項目の記述とともに示す。 表 5 には各因子の $\alpha$ 係数の值も示す。因子 $1,2,3$, 5 の $\alpha$ 係数は 0.7 よも大きく, 尺度の信頼性は高い とみなされる。他の因子の $\alpha$ 係数が低いのは, 各因 子に含まれる項目数が少ないことによると思われる。 各項目の最大因子負荷量を太字とハイライトで示す。

理想的には, 予備調査の段階で 2 国間の因子構造 に大きな違いがないことが確認されてから本調査を 行うことが望ましいが, 公的な調査でない限り, 予 備調査で因子分析を行うのに十分なデー夕数を集め ることは非常に難しい。そこで本研究においては, デー夕収集後, 米国デー夕のみ, 日本デー夕のみ, さらに日米のデータについて独立に因子分析を行 い，因子構造に大きな矛盾がないかどうかを検討し た。どの場合も 10 の主成分が抽出され, 同一の因子 構造をもつことが明らかになったので, 本論文では 両国を含める形で，全体に対する因子分析結果のみ を取り上げた。また， 1 国で因子分析を行う際のデー 夕数に関して, 質問項目のカテゴリーの中で一番多 いのが「(2)探究的学習における生徒の活動の重要性」 (行動面)の 21 項目であり, 米国 57 件のサンプル数 はその約 3 倍を満足している。また, 米国のみの因 子分析における信頼性は, アルファが 0.77 と十分に 高かったことから確かめられている。さらに, 因子 分析においてサンプル数よりも共通性が重要である という議論もあり（MacCallum ら，1999），米国のみ
のデータにおいて各項目の共通性は 0.6 以上である ことを確認し、サンプル数が少ないという懸念はな いと判断した。

0.50 をカットオフ值として用いた場合, 36 項目中 28 項目が 10 因子の内の 1 因子のみに負荷するとい うロバストな結果が得られた。この結果はこの尺度 が10因子によって記述されることを示すものであ る。網掛けで示した 8 項目はいずれの因子にも 0.50 以上の負荷が見られない。そこで，尺度全体の因子 構造を分析するという目的に沿って，以下の議論で は 0.50 以上の負荷因子が見られる 28 項目のみを考 慮することにする。

それぞれの因子に含まれる項目の特徴から，因子 名を検討した。結果を表 6 に示す。因子 1 には生徒 が説明を考え出したり（項目 12）, 伝えたり（項目 20）という探究的活動を大事に思うかどうかを問う 項目が含まれており，そのような活動は全米科学教 育スタンダードに探究的として記述されているよう に科学の方法に則った探究的指導であるから「科学 の方法に則った探究的指導」とした。因子 2 には 3 つのカテゴリーに属する項目が含まれている。その 内の 2 項目が生徒の自主的な行動に関するもの（項 目 8，24）であることが特徴的である。また, 残り の 3 項目（項目 $35 ， 36 ， 3$ ）は探究的指導ができる と思う教員の気持ちによるものであるから，「生徒の 自主的な活動と教員の探究的指導に対する自信」と した。因子 3 は探究的活動の妨げとなることに関す る項目（項目 32，33，34）を含むところから「探究 的指導に関して妨げとなる時間的・物的制限」とし た。因子 4 は生徒を助けることに関する項目（項目 28，23）と中学校における探究的活動の重要性（項 目 1）を含むことから「生徒への支援と探究的指導 法の重要性」とした。因子 5 は生徒の質問に関する 項目（項目 $26 ， 27$ ），および説明の正当性や実験方 法の妥当性を議論するメ夕認知的な項目（項目 25 , 21）が含まれていることから「生徒の質問への対応 と高次の思考」とした。因子 6 は教科書や教師用指 導書の使用に関する項目（項目 22，15）を含むとこ ろから,「科学的概念の正しさ」とした。因子 7 は現 実社会との結びつき（項目 19）や探究する技能の習 得（項目 5) など，探究活動に付随して間接的に述 べられていることに関する項目を含むことから，「探 究的指導に関して二次的に重要な要素」とした。因 子 8 から 10 は 1 項目のみを含む因子であり, 項目の 内容をそのまま因子名とした。因子 8 は「探究的指 導に関して妨げとなる試験」，因子 9 は「教員の満足 度」, そして因子 10 は「学級全体の理解」とした。 


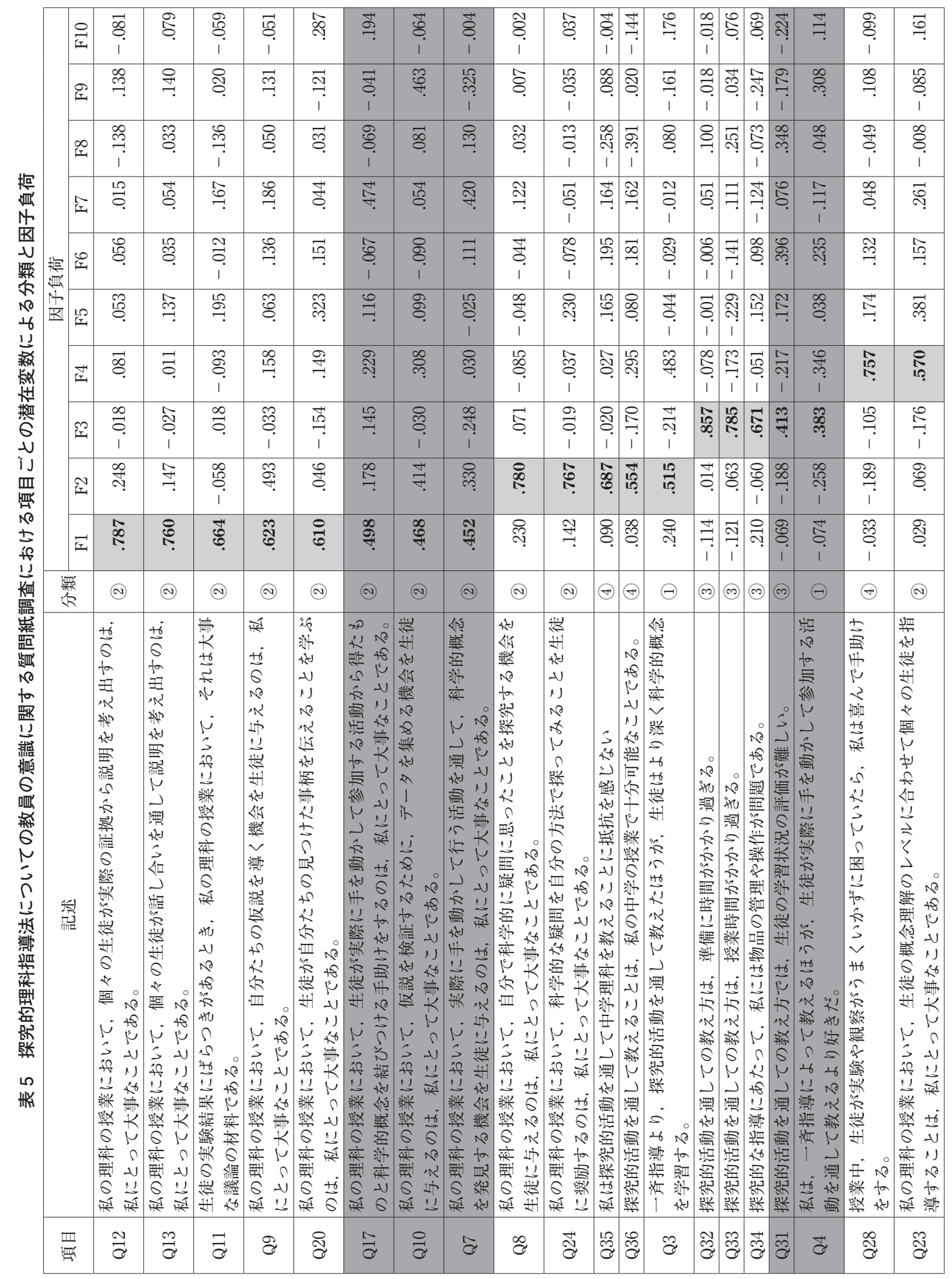




\begin{tabular}{|c|c|c|c|c|c|c|c|c|c|c|c|c|c|c|c|c|c|c|c|}
\hline $\mathscr{g}$ & 范. & \& & 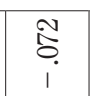 & $\stackrel{\infty}{\stackrel{\infty}{?}}$ & $\begin{array}{l}\mathscr{I} \\
\stackrel{0}{0}\end{array}$ & 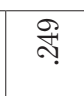 & $c$ & $\mathscr{\sigma}$ & ஜ̊ & 范 & 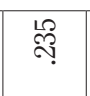 & ? & & S & $\underset{\infty}{10}$ & 8 & & & $\stackrel{\|}{\oplus}$ \\
\hline $\overrightarrow{\mathcal{I}}$ & 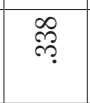 & 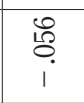 & 苞 & $\stackrel{0}{\circ}$ & $\hat{8}$ & $\bar{\delta}$ & స̆ & $\widehat{\stackrel{\leftrightarrow}{\circ}}$ & $\underset{\sharp}{\infty}$ & $i$ & $\vec{\varpi}$ & $\mathscr{m}_{i}$ & & 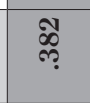 & $\ddot{m}$ & & : & & 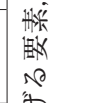 \\
\hline ? & $\stackrel{\infty}{\rightarrow}$ & ? & $\begin{array}{l}\stackrel{8}{?} \\
1\end{array}$ & $\ddot{8}$ & 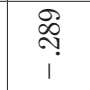 & oे & 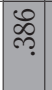 & ஜ̊ & $\begin{array}{l}\infty \\
\infty \\
\infty\end{array}$ & 1 & $\begin{array}{l}8 \\
\\
i\end{array}$ & స్ & & 0 & $\stackrel{8}{\circ}$ & & $\frac{10}{10}$ & & \\
\hline ஜ̊ & 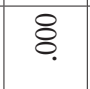 & 跑 & 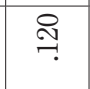 & $\stackrel{\Omega}{f}$ & $\stackrel{\infty}{0}$ & $\Xi$ & ชิ & $\vec{\delta}$ & $\begin{array}{l}\mathscr{0} \\
\mathscr{0}\end{array}$ & $\underset{10}{8}$ & है & ஜ̊. & 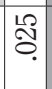 & $\stackrel{m}{\sim}$ & $\begin{array}{l}12 \\
5 \\
0\end{array}$ & $=$ & 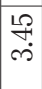 & & 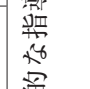 \\
\hline$\underset{i}{*}$ & 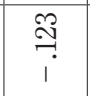 & จ & $\begin{array}{c}\text { S } \\
\text { ஸุ } \\
1\end{array}$ & ণ্ণি & छ̣ & $\begin{array}{l}\infty \\
\infty\end{array}$ & $\stackrel{\infty}{\underset{f}{f}}$ & ஜ̊ & $\stackrel{m}{0}$ & i & ণ̦ & ô. & $\vec{I}$ & $\stackrel{-}{1}$ & 8 & 踪 & $\underset{+}{\vec{f}}$ & & 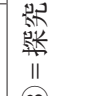 \\
\hline $\begin{array}{l}\text { g. } \\
\text { s. } \\
\text {. }\end{array}$ & $\begin{array}{l}\text { Iै } \\
0 \\
0\end{array}$ & สิ & రొ & II & 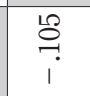 & $\overrightarrow{8}$ & ชิ & $\stackrel{\stackrel{L}{\oplus}}{\text { ஸे }}$ & $\underset{t}{+}$ & $\stackrel{\infty}{\stackrel{\circ}{\delta} .}$ & $\stackrel{\text { త్ }}{\text {. }}$ & 18 & $\Xi$ & 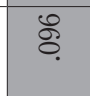 & 8 & 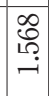 & $\begin{array}{l}\mathscr{2} \\
\stackrel{+}{*}\end{array}$ & & \\
\hline चี & $\ddot{\circ}$ & $\hat{0}$ & $\mathbb{8}$ & $\mathscr{0}$ & $\vec{m}$ & 8 & $=$ & సิ & 战 & $\stackrel{\circ}{\circ}$ & $\underset{\text { Iิ }}{\text { i }}$ & 8 & 趈 & $\begin{array}{l}\mathscr{\infty} \\
\underset{1}{\longrightarrow}\end{array}$ & ஜे & $\infty$ & \begin{tabular}{|l|}
$\vec{~}$ \\
is
\end{tabular} & $\stackrel{8}{8}$ & 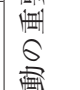 \\
\hline$\underset{\text { I }}{\stackrel{?}{?}}$ & 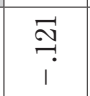 & $\stackrel{\stackrel{1}{\Im}}{\rightarrow}$ & $\stackrel{\mathbb{I}}{\overparen{C}}$ & $\begin{array}{l}0 \\
\text { s. } \\
\text { i }\end{array}$ & $\begin{array}{l}\mathscr{N} \\
\text { N̦ }\end{array}$ & $\stackrel{\widehat{S}}{\hookrightarrow}$ & $\begin{array}{l}\infty \\
\stackrel{y}{f}\end{array}$ & $\begin{array}{c}\underset{\infty}{0} \\
\stackrel{N}{1} \\
\text { । }\end{array}$ & $\underset{\mathscr{~}}{\tilde{i}}$ & 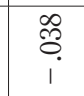 & ণิ ণุ & 車 & ন़ & 苂 & $\vec{\delta}$ & $\infty$ & $\begin{array}{l}\infty \\
\infty \\
0\end{array}$ & 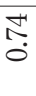 & \\
\hline ঙ̊ & $\begin{array}{l}\infty \\
\stackrel{8}{o} .\end{array}$ & ? & 8 & $\vec{m}$ & $i$ & ঐ্ & స় & తి & ڤి & ஜ్లి & $\underset{\text { I }}{\exists}$ & 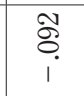 & m్ & ল্ল & $\begin{array}{l}\mathscr{O} \\
\text { Oे } \\
\text { । }\end{array}$ & $\stackrel{N}{N}$ & $\begin{array}{l}\vec{J} \\
\text { ă }\end{array}$ & & \\
\hline$\underset{\sim}{\infty}$ & $\stackrel{\infty}{\circ}$ & $\stackrel{?}{1}$ & 占 & ఝొ & $\mathscr{\Omega}$ & $\mathscr{\&}$ & is & $\stackrel{\infty}{\stackrel{\infty}{\nearrow}}$ & $\begin{array}{l}\widehat{\infty} \\
\stackrel{\infty}{N}\end{array}$ & $\begin{array}{l}\stackrel{8}{8} \\
\stackrel{8}{f}\end{array}$ & $\begin{array}{l}\mathscr{0} \\
\stackrel{0}{0}\end{array}$ & $\stackrel{1}{8}$ & $\hat{6}$ & $\begin{array}{l}\mathscr{0} \\
\text { है }\end{array}$ & fr & đ̦ & 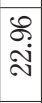 & $\begin{array}{c}\infty \\
\infty \\
0\end{array}$ & \\
\hline$\Theta$ & $\oplus$ & (ㄱ) & $\oplus$ & (ง) & & & (2) & 0 & (ㄱ) & & 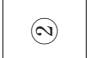 & (2) & $\Theta$ & (ㅇ) & (ง) & & & & \\
\hline 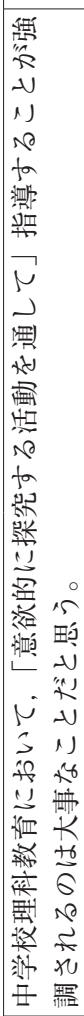 & 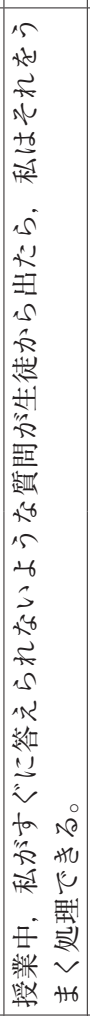 & 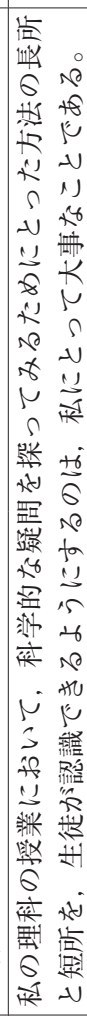 & 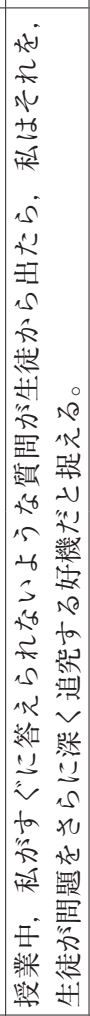 & 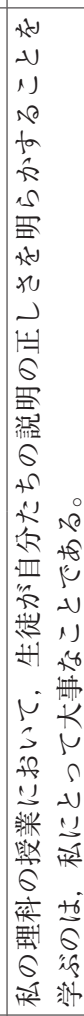 & 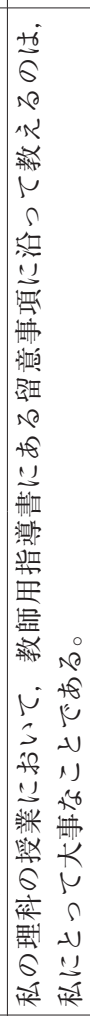 & 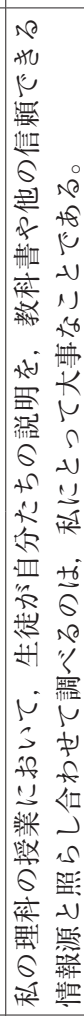 & 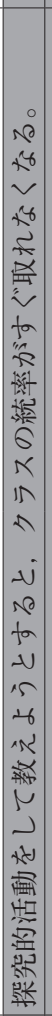 & 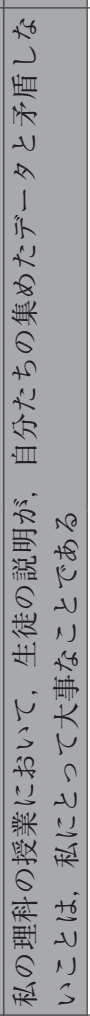 & 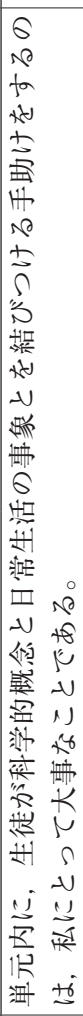 & 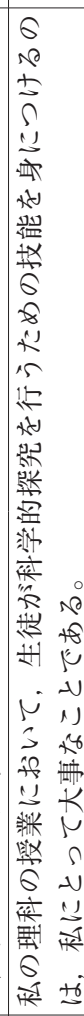 & 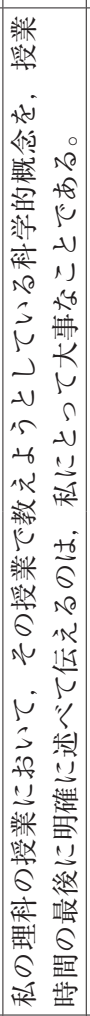 & 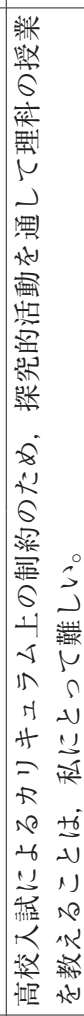 & 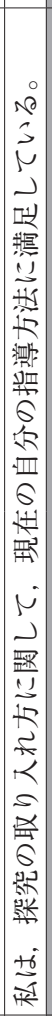 & 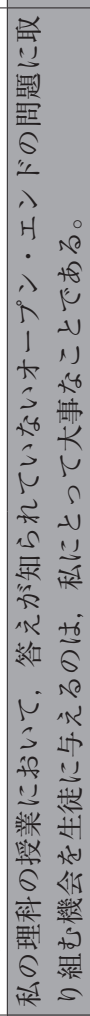 & 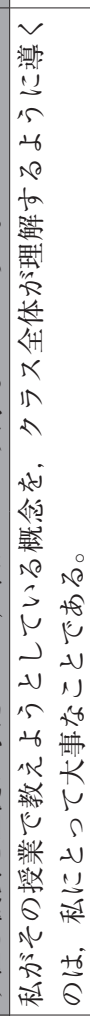 & & 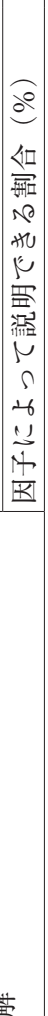 & 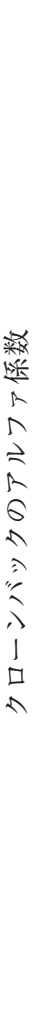 & 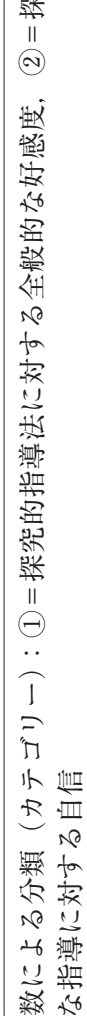 \\
\hline$\vec{\sigma}$ & ฮี & & 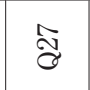 & 0 & 8 & $\stackrel{10}{\sigma}$ & & $\sigma$ & 8 & $\stackrel{10}{\sigma}$ & & & & $\sigma$ & 8 & & & & \\
\hline
\end{tabular}


表 6 各因子における国別の平均（標準偏差）と国による効果

\begin{tabular}{|c|c|c|c|c|c|c|}
\hline \multirow{2}{*}{ 因子 } & \multirow{2}{*}{ 因子名 } & \multicolumn{2}{|c|}{ 平均（標準偏差） } & \multirow{2}{*}{$\mathrm{F}$ 值 } & \multirow{2}{*}{$\mathrm{p}$ 值 } & \multirow{2}{*}{$\begin{array}{c}\text { 偏イータ } \\
2 \text { 乗 }\end{array}$} \\
\hline & & 日本 $(\mathrm{N}=134)$ & 米国 $(\mathrm{N}=57)$ & & & \\
\hline 因子 1 & 科学の方法に則った探究的指導 & $4.14(0.57)$ & $4.44(0.40)$ & 9.18 & $0.003^{*}$ & 0.062 \\
\hline 因子 2 & 生徒の自主的な活動と教員の探究的指導に対する自信 & $3.93(0.59)$ & $4.17(0.51)$ & 3.46 & 0.065 & 0.024 \\
\hline 因子 3 & 探究的指導に関して妨げとなる時間的・物的制約 & $3.48(0.79)$ & $2.76(0.85)$ & 27.18 & $0.001^{*}$ & 0.163 \\
\hline 因子 4 & 生徒への支援と探究的指導法の重要性 & $3.99(0.57)$ & $4.46(0.72)$ & 43.92 & $0.001^{*}$ & 0.239 \\
\hline 因子 5 & 生徒の質問への対応と高次の思考 & $3.95(0.52)$ & $4.41(0.41)$ & 28.68 & $0.001^{*}$ & 0.170 \\
\hline 因子 6 & 科学的概念の正しさ & $3.41(0.62)$ & $3.35(0.69)$ & 0.33 & 0.568 & 0.002 \\
\hline 因子 7 & 探究的指導に関して二次的に重要な要素 & $4.24(0.47)$ & $4.35(0.46)$ & 0.75 & 0.389 & 0.005 \\
\hline 因子 8 & 探究的指導に関して妨げとなる試験 & $3.19(1.17)$ & $3.49(1.16)$ & 1.63 & 0.204 & 0.012 \\
\hline 因子 9 & 教員の満足度 & $2.93(0.92)$ & $3.42(1.08)$ & 10.15 & $0.002 *$ & 0.068 \\
\hline 因子 10 & 学級全体の理解 & $4.33(0.68)$ & $4.18 \quad(0.87)$ & 1.49 & 0.224 & 0.011 \\
\hline
\end{tabular}

* 統計的有意 $(\mathrm{p}<0.05)$

\section{3 国による主効果の検定}

表 6 にはそれぞれの国ごとの各因子に含まれる項 目の平均値と標準偏差を示す。 5 件法で回答を求め た28の各質問項目について,「まったくそう思わな い」=1点から「強くそう思う」 $=5$ 点の範囲で点 数化している。国を固定因子として 10 個の従属変 数に対して多変量分散分析を行った。ウィルクスの ラムダ指標を用いると，10因子を合成した従属変 数に対して，国による差が有意であることがわかっ た（F值 $=11.99, \mathrm{p}$ 值 $<0.001 ） 。$ 偏イータ 2 乗によ る効果量は 0.48 であり, 中程度の効果と考えられる (Cohen, 1992)。全体的に国による有意差が生じてい ることが明らかになった上で, 各因子を従属変数と して扱い, 1 変量分散分析によって国による差が有 意かどうかの検定を行った。その結果を表 6 に示す。 Bonferroni の方法を用いて 10 個の従属変数について 有意水準の切り下げ $(0.05 / 10=0.005)$ を行った後, 因子 $1 ， 3 ， 4 ， 5$ および 9 で国による有意差が生じ ていることがわかった。例えば, 因子 1 の「科学の 方法に則った探究的指導」では, 国による主効果が 有意であり（ $\mathrm{F}$ 值 $=9.18, \mathrm{p}$ 值 $=0.003$, 偏イータ 2 乗 $=0.62)$, 日本よりも米国の得点が高かった。以下 に, 分析結果の解釈を述べる。

\section{4 分析結果の解釈}

計量心理学的要素を考慮した際のカテゴリー(3)の 探究的指導法に関して妨げとなることを問う項目は, 因子 3 と 8 にすべて集まった。また，カテゴリー(4) の探究的指導法に対する自信を問う項目も, 因子 2 , 4, 5 という特定の因子に負荷した。理科の探究的指 導に関して教員の態度を定義するために用いた下位 のカテゴリーが, 分析の過程で現れたことは大変興
味深い。この結果は質問紙の尺度が, 本研究の潜在 変数をよく表しているものと考えることができる。

因子 1 の平均点は米国教員 $\mathrm{M}=4.44$, 日本教員 $\mathrm{M}$ $=4.14$ であり, どちらの国の教員も科学の方法に 則った探究的指導の要素に強く賛成していることが わかる。例えば，どちらの国の教員も，理科授業内 に生徒が証拠から説明を考え出すこと（項目 12）を 重要だと思っている（項目平均は日本 $\mathrm{M}=4.25$, 米 国 $\mathrm{M}=4.45)$ 。しかし，因子 1 の 1 変量分散分析にお いて国による差が有意 $(\mathrm{p}=0.003)$ であったことか ら，日本の教員は米国教員に比へ，科学の方法に 則った探究的指導法を重要に思う度合いが低いと言 える。また, 因子 9 において, 統計的有意差 $(\mathrm{p}=$ 0.002）が見られたということは，日本の教員（M= 2.93）が米国教員（M=3.42）に比べて，理科授業に おける探究的指導法の使い方に満足していないという ことを表している。日本の教員が探究的指導法に対 して躊躇する理由の 1 つに, 日本の理科カリキュラ ムにおける時間的制約の厳しさがあることが考えら れる。調查時の日本の中学校理科授業数は年間 105 時間であり（文部科学省，1999），平均して年間 135 時間の理科授業がある米国（NCES, 2005）との差は 30 時間と大きい。探究的指導法を実践する上で，日 本の教員の時間的・物的制約に対する懸念が米国教 員に比べて大きいことは，因子 3 の「時間的・物的 制限」の分析結果（日本 $\mathrm{M}=3.48$, 米国 $\mathrm{M}=2.76)$ の上でも有意差をもって現れている $(\mathrm{p}<0.001)$ 。

さらに，因子 4 において示されたことは，生徒の 探究的な活動を支援することと探究的指導法の重要 性に関して，日本の教員は米国の教員に比べて積極 的に賛成しておらず，その差は統計的に有意であっ たということである（日本 $\mathrm{M}=3.99$, 米国 $\mathrm{M}=4.46$, 
$\mathrm{p}<0.001)$ 。また, 因子 5 が示すように, 生徒の質問 に対応することと高次の思考に関して, 日本の教員 は米国教員に比べて躊躇する傾向があり, 統計的に 有意な差が見られた（日本 $\mathrm{M}=3.95$ ，米国 $\mathrm{M}=4.41$, $\mathrm{p}<0.001)$ 。統計的有意差の見られた因子 4 と因子 5 に共通する内容は, 日本の教員は授業中, 生徒の探 究的な活動を助けたり質問に答えたりすることに, 米国の教員に比べて積極的でないということである。 これらの結果は Rothら（2006）による先行研究では 触れられていなかった内容である。次に結果の意味 を考察する。

\section{4. 考察}

探究的指導法に関して, 日米の中学校理科教員の 意識について質問紙を用いて調べた結果から, 日米 双方の教員が全米科学教育スタンダードに述べられ ているような科学の方法に則った探究的指導法を強 く支持していることがわかった。しかし，日本の教 員が支持する度合いは米国教員に比べ統計的有意な 差をもって低かった。また, 日本の教員は米国教員 に比べ, 授業中, 生徒の探究的な活動を助けたり, 質問に答えたりすることを躊躇する傾向にあること がわかった。

\section{1 授業観察結果との関連}

ここで得られた結果を, 先行研究 (Tosa, 2009; 2011）の中学校理科授業の観察結果と関連付けて考 察する。日本で観察された授業において, 予想, 実 験・観察, 考察という探究的要素を含む割合が大き いということを前述したが, これは本研究の質問紙 調査において, 日本の教員が科学の方法に則った探 究的指導法に強く賛成する $(\mathrm{M}=4.14)$ という結果 と一致する。また, 前述したように, 日本の授業で は教員が生徒に積極的に働きかけたり, 自主的な概 念構築や既有知識との関連付けを促したりすること が少ないということが先行研究によって明らかにさ れたが，本研究の質問紙調査で新たに明らかになっ たのは, 教員自身が生徒の活動や疑問を助けること を躊躇する意識をもっているということである。生 徒の概念形成を積極的に助けていないという実際に 観察された行動は, 教員の意識から発するものであ ることが裏付けられた。

\section{2 教員インタビュー結果との関連}

前述したように, 先行研究（Tosa, $2009 ； 2011 ） の$ インタビュー調査を通して, 日本の中学校理科教員 の多くが, 授業中, 生徒の活動の結果から科学的概
念を導くことを重視していたことが明らかにされた が，これは本研究の質問紙調査で，日本の教員が「1 人ひとりの生徒が実験から説明を考え出す (Q12)」 などの科学の方法に則った探究的指導法に強く賛成 するという結果と一致する。

他方, 教員が助けてしまっては, 生徒の思考力を 伸ばすことにならないとインタビューで述べた教員 がいたことは，生徒を助けることを躊躇するという 質問紙調查を通して明らかになった傾向とつながる と考えられる。探究的指導法において, 生徒の概念 理解を促すような教員の働きかけは重要な役割をも つ（全米科学教育スタンダード, p. 33，1996）。日本 の教員の「教員が助けてしまっては, 生徒の考力を 伸ばすことにならない」という考えは，実際にどの ような手法をとれば生徒の概念形成を助けることに なるのかが，十分に認識されていないことによるの かもしれない。拉そらく，生徒を助けるということ は，正解を与えることだと捉えられており，ソクラ テスの問答形式的な質問 (Knezic ら, 2010) など, 米国で効果的と考えられている手法が日本ではまだ 十分に広まっていないということも考えられる。現 に，教員の積極的な働きかけではなく，単に時間を 与えて生徒から答えが出るのを期待するという手法 が文献に見られる（藤田，2009）。

\section{3 教科内容と教育学的知識に関する背景}

本研究において明らかになった日米の中学校理科 教員の意識の違いは，教員自身の教育歴における経 験が影響しているとも考えられる。表 1 のデータが 代表するように，日本の中学校理科教員回答者には 理科関係だけの学部・大学院を卒業した者が $64 \%$ を 占める。他方, 米国回答者の中で理学系のみの出身 者は $14 \%$ と少なく, 教育学部を出たか $(29 \%)$, 理 学部を出た後に教育学の大学院へ行った者が多い $(51 \%)$ 。すなわち， $80 \%$ の回答者が教育学系に籍を 置いたことがある米国と比べ，日本の回答者の $64 \%$ は教育学を専門に学んだ経験をもっていないことが わかる。これは生徒に積極的に働きかけるという教 育学的手法を躊躇するという日本の中学校理科教員 の傾向を説明する要因の一つに挙げられるだろう。

対照的に, 教科内容に関する知識について考えるな らば，教育学部でも理学部と同様に教科内容の研究を 専門とする大学教員の多い日本では, 中学校教員志望 の学生が教科内容の専門的な学習経験をもつ場合も多 い。しかし, 米国では教育学部の理科教員は, 教育 学の専門家である場合が多く, 教科内容に関する知 識を専門的に深める機会はあまりない（McDermott 
\& DeWater, 2000)。また，米国には日本のように検定 済み教科書がないので, 内容の多様性が大きく, 日 本に比べ，教科内容に関して何をどのように教える べきか確固として定まっていない場合が多いと言えよ う。教科内容に関する日米の比較は, 今回の質問紙調 査の範囲外であるが，教科内容と教育的な手法は常 にセットになって考えられるものである (Schulman, 1986)。今後, 本研究で明らかになった日米の教員の 意識の違いに加え, 教科内容に関する教員の知識に ついて調査を行い, 教科内容と指導法の両面に着目 した特徴を明らかにする必要があるだろう。

\section{4 研究の限界}

本研究の対象となった参加者は, 日米の理科教育 関係のメーリングリストの登録者の中でも自ら研究 に参加を申し出た現職の中学校理科教員である。本 研究の対象が日米の中学校理科教員全体を代表して いるとは言い難い。しかし, 前述したように, 公的 な調査でない限り, 無作為に抽出された学校教員か ら回答を得ることは難しい。本研究は, 日米共に中 学校理科教員という全体の中の, 探究的指導法の調 査に関心をもった一部を対象とし, 実施可能な方法 を用いたと考えてよいだろう。

調査において, 日本語と英語の 2 力国語が用いら れることにより, 曖昧な点が生じることが危惧され る。調查に使われた質問紙は，まず英語で作成され， 米国の専門家によって内容検討がなされた後に日本 語に翻訳された。試験調查を行う前に, 日本の理科 教育研究者によって翻訳された日本語版の確認が行 われた。さらに, 他の研究者が日本語版を英訳し直 し, 元の英語版と比較して意味の変更がないことが 確かめられた。言語の違いから生じる意味の取り違 えは，極力回避する措置が取られたと言えよう。

\section{5. 成果と今後の課題}

以上の結果と考察から, 本研究に参加した日米両 国の中学校理科教員は, 文化的背景が異なりながら も, 米国科学教育スタンダードで述べられている ような科学の方法に則った探究的指導法に強く賛 成することが明らかになった。しかし, 日本の教員 は授業中, 生徒の探究的な活動を助けたり質問に答 えたりすることについて, 米国の教員に比べて積極 的に賛成しておらず，それは授業観察調査やインタ ビュー調査で得られた結果とも一致するものであっ た。1つの理由として日本の中学校理科教員の多く は教育学を専門的に学ぶ機会が少ないことが挙げら れる。状況は教育学部を卒業する必要がある小学校
の場合には異なると予想される。小学校理科に関し て同様の日米比較研究が望まれることから, 研究を 遂行中である。

日本の中学校理科教員の多くを占める理学部系出 身者にとって必要なのは, 教科内容に沿って生徒の 概念理解を促すための教育学的手法の獲得であろう。 それには科学的概念に関する深い知識を基に指導法 の洗い直しを行い, 教育学的知識と融合させ, 実践 知まで高める訓練が必要になる。伝統的に培ってき た，教員の教科内容に関する強みを活かし，その上 に加えられることが有効であろう。昨吟注目されて いる教職大学院でも, 教科内容の専門性と教育学的 手法の融合を目指す課程が望まれる。今後さらに調 査を進め, 日米比較に基づく提言を続けたい。

\section{引用文献}

Achieve (2015). Three Dimensions, Next Generation Science Standards web site. Retrieved from http://www. nextgenscience.org/three-dimensions

Anderson, R.D. (2002). Reforming science teaching: What research says about inquiry. J. of Science Teacher Education, $13,1-12$.

Bybee, R. (2000). Teaching science as inquiry. In J. Minstrell \& E.H. van Zee (Eds.). Inquiring into Inquiry Learning and Teaching in Science. Washington, DC: American Association for the Advancement of Science, 21-46.

Cohen, J. (1992). A power primer. Psychological Bulletin, 112, 155-159.

Comrey, A.L., \& Lee, H.B. (1992). A first course in factor analysis. Hillsdale, NJ: Lawrence Erlbaum Associates.

DeVellis, R.F. (2003). Scale development: Theory and application. Thousand Oaks, CA: Sage.

藤田留三丸（2009）「学びの過程の振り返り」『月刊理科教育」 第 58 号, 20-22.

Gable, R.K. (1986). Instrument development in the affective domain. Hingham, MA: Kluwer Academic.

International Association for the Evaluation of Educational Achievement (IEA). (2007). TIMSS 2007 Int'l Science Report, 262.

Knezic, D., Wubbels, T., Elbers, E., \& Hajer, M. (2010). The Socratic dialogue and teacher education. Teaching and Teacher Education: An Int'l J. of Research and Studies, 26(4), 1104-1111.

Koballa, T.R., \& Crawley, F.E. (1985). The influence of attitude on science teaching and learning. School of Science and Mathematics, 85(3), 222-232.

国立教育政策研究所（2015a）「OECD 生徒の学習到達度調査 (PISA) 」Retrieved from http://www.nier.go.jp/kokusai/pisa/ 国立教育政策研究所 (2015b)「IEA 国際数学・理科教育動 
向調査（TIMSS）」Retrieved from http://www.nier.go.jp/ timss/index.html

国立教育政策研究所編（2014）「教員環境の国際比較一OECD 国際教員指導環境調査（TALIS）2013 年調査結果報告 書」明石書店.

Lawson, A.E. (1990). Science education in Japan and the United States: Are the Japanese beating us at our own game?. Science Education, 74(4), 495-501.

Linn, M.C., Lewis, C., Tsuchida, I., \& Songer, N.B. (2000). Beyond fourth-grade science: Why do U.S. and Japanese students diverge?. Educational Researcher, 29(3), 4-14.

Lotter, C. (2004). Preservice science teachers' concerns through classroom observations and student teaching: Special focus on inquiry teaching. Science Educator, 13(1), 29-38.

MacCallum, R.C., Widaman, K.F., \& Hong, S. (1999). Sample size in factor analysis. Psychological Methods, 4, 84-99.

Martin, M.O., Mullis, I.V.S., Foy, P., \& Hooper, M. (2016). TIMSS 2015 International Results in Science. Retrieved from Boston College, TIMSS \& PIRLS International Study Center website: http://timssandpirls.bc.edu/timss2015/ international-results/

McDermott, L.C., \& DeWater, L.S. (2000). The need for special science courses for teachers: Two perspectives. In J. Minstrell \& E.H. van Zee (Eds.). Inquiring into inquiry learning and teaching in science. Washington, DC: American Association for the Advancement of Science, 241-257.

文部科学省 (2008)「中学校学習指導要領」

文部科学省 (2016) 「数学・理科にわたる探究的科目の在 り方について」, 教育課程部会資料 3 , Retrieved from http://www.mext.go.jp/b_menu/shingi/chukyo/chukyo3/ 070/siryo/_icsFiles/afieldfile/2016/05/11/1370456_3_1.pdf

文部科学省 (2017)「次期中学校学習指導要領」Retrieved from http://www.mext.go.jp/b_menu/shingi/chukyo/ chukyo3/070/siryo/_icsFiles/afieldfile/2016/05/11/ 1370456_3_1.pdf

National Center for Education Statistics [NCES]. (2005). Instructional practices and time spent teaching science in eighth grade, by country: 2003 (NCES Table No. 399).

National Center for Educational Statistics [NCES] (2015; 2011; 2007; 2003; 1999; 1995). TIMSS Questionnaires. Retrieved from https://nces.ed.gov/timss/questionnaire.asp

National Research Council [NRC]. (1996). National Science Education Standards. Washington, DC: National Academic Press, 1-102.

National Research Council (2000). Inquiry and the National Science Education Standards: A guide for teaching and learning. Washington, DC: National Academic Press, 1-38.

National Science Teacher Association [NSTA]. (2004). Scientific inquiry, NSTA Position Statement. Retrieved from http:// www.nsta.org/docs/PositionStatement_ScientificInquiry.pdf
小倉康（2004）「わが国と諸外国における理科授業のビデオ 分析とその教師教育への活用効果の研究」国立教育政 策研究所, 第 1 部 \#12308007, 218-245.

Reiff, R. (2002). If inquiry is so great, why isn't everyone doing it? Paper presented at the Annual International Conference of the Association for the Education of Teachers in Science, Charlotte, NC.

Roth, K.J., Druker, S.L., Garnier, H.E., Lemmens, M., Chen, C., Kawanaka, T., et al. (2006). Teaching Science in Five Countries: Results From the TIMSS 1999 Video Study (NCES 2006-011). U.S. Department of Education, National Center for Education Statistics. Washington, DC: U.S. Government Printing Office, 66-67.

Schulman, L.S. (1986). Those who understand: Knowledge growth in teaching. Educational Researcher, 15, 4-14.

Shrigley, R.L., Koballa, T.R., Jr., \& Simpson, R.D. (1988). Defining attitude for science educators. $J$. of Research in Science Teaching, 25(8), 659-678.

Simmons, P.E., Emory, A., Carter, T., Coker, T., Finnegan, B., Crockett, D., et al. (1999). Beginning teachers: Beliefs and classroom actions. J. of Research in Science Teaching, 36(8), 930-954.

Smolleck, L.D., Zembal-Saul, C., \& Yoder, E.P. (2006). The development and validation of an instrument to measure preservice teachers' self-efficacy in regard to the teaching of science as inquiry. J. of Science Teacher Education, 17, 137-163.

Stigler, J.W., Gallimore, R., \& Hiebert, J. (2000). Using video surveys to compare classrooms and teaching across cultures: Examples and lessons from the TIMSS Video Studies. Educational Psychologist, 35(2), 87-100.

Takemura, S., Matsumoto, K., Yoshida, A., Matsumoto, S., Hioki, M., Saruta, Y., et al. (1985). The Japan-US cooperative science program. Unpublished report. Hiroshima University.

Takemura, S., \& Shimizu, K. (1993). Goals and strategies for science teaching as perceived by elementary school teachers in Japan and the United States. Peabody J. of Education, 68(4), 23-33.

Tosa, S. (2011). Comparing US and Japanese inquiry-based science practices in middle schools. Middle Grades Research J., 6(1), 29-46.

Tosa, S. (2009). Teaching science as inquiry in US and in Japan: A cross-cultural comparison of science teachers' understanding of, and attitudes toward inquiry-based teaching. Unpublished doctoral dissertation, Univ. of Massachusetts Lowell.

Von Secker, C. (2002). Effects of inquiry-based teacher practices on science excellence and equity. The J. of Educational Research, 95(3), 151-160. 


\title{
Are Japanese Lower-Secondary-School Science Lessons More Inquiry-Oriented than U.S. Lessons?
}

-A Japan-U.S. Comparative Study on Lower-Secondary-School Science Teachers' Attitudes through a Survey Analysis-

\author{
Sachiko TOSA ${ }^{1}$ \\ ${ }^{1}$ Faculty of Education, Niigata University
}

\begin{abstract}
SUMMARY
Since the publication of the National Science Education Standards (NSES) in 1996, learning science through inquiry has been regarded as the heart of science education in the U.S.A. However, the TIMSS 1999 Science Video Study showed that inquiry-based teaching has been taking place less in the U.S. than in Japan. This study examined similarities and differences in how American and Japanese lower-secondary-school science teachers think and feel about inquiry-based teaching. Teachers' attitudes and beliefs toward the use of inquiry in science teaching were measured through a newly developed survey instrument called STAIB (survey for measuring Science Teachers' Attitudes towards Inquiry-Based teaching) $(n=191)$. The psychometric development of the attitude scale is described. An exploratory factor analysis identified 10 factors that characterize lowersecondary-school science teachers' attitudes and beliefs, and a multivariate analysis with country as a factor variable was performed for the 10 factors. The results show that country has a significant main effect on the overall factor scores. The univariate analysis on each of the factors identified five specific areas toward which U.S. and Japanese teachers felt differently. The results indicated that U.S. teachers more strongly agreed with inquiry-based teaching that promotes the use of the scientific method than teachers in Japan did. Furthermore, the results indicated that Japanese teachers felt less comfortable in helping student activities and questions than American teachers did. The cultural implications of the findings, including the differences in teacher education systems, are discussed.
\end{abstract}

$<$ Key words $>$ lower-secondary-school science, international comparative study, inquiry-based teaching, TIMSS Science Video Study 